\title{
From smart to rebel city? Worlding, provincialising and the Barcelona Model
}

\section{Greig Charnock}

The University of Manchester, UK

\section{Hug March}

Universitat Oberta de Catalunya, Spain

\section{Ramon Ribera-Fumaz}

Universitat Oberta de Catalunya, Spain

\begin{abstract}
This article examines the evolution of the 'Barcelona Model' of urban transformation through the lenses of worlding and provincialising urbanism. We trace this evolution from an especially dogmatic worlding vision of the smart city, under a centre-right city council, to its radical repurposing under the auspices of a municipal government led, after May 20I5, by the citizens' platform Barcelona en Comú. We pay particular attention to the new council's objectives to harness digital platform technologies to enhance participative democracy, and its agenda to secure technological sovereignty and digital rights for its citizens. While stressing the progressive intent of these aims, we also acknowledge the challenge of going beyond the repurposing of smart technologies so as to engender new and radical forms of subjectivity among citizens themselves; a necessary basis for any urban revolution.
\end{abstract}

\section{Keywords}

citizenship, place branding, policy, politics, provincialising, technology/smart cities 


\begin{abstract}
摘要
本文从世界主义和地方主义城市化的角度审视了巴塞罗那模式的演变。从中右翼市议会 特别教条化的世界主义智慧城市愿景, 到2015年5月后由市民组织 “共同的巴塞罗那” (Ba rcelona en Comu)

领导的市政府对智慧城市的彻底重新定向, 我们追溯了这一演变过程。我们特别关注新 政府利用数字平台技术加强参与性民主的目标, 及其确保公民技术主权和数字权利的议 程。在强调这些目标的进步意图的同时, 我们也认识到了这样的挑战: 即超越智能技术 的重新定向, 以在公民自身中产生新的和激进的主观性形式; 这是任何城市革命的必要 基础。
\end{abstract}

\title{
关键词
}

公民身份、地方品牌化、政策、政治、地方化、科技/智慧城市

Received December 2018; accepted August 2019

\section{Introduction}

Long before the ascent of the smart city agenda, the city of Barcelona was a widely acknowledged referent for global urbanism. From the early 1990s onwards, the so-called 'Barcelona Model' encapsulated the supposed virtues of top-down strategic urban planning; the ability of city planners to adapt urban policy according to changes in the wider landscape of inter-urban competition and dominant understandings of urban growth; and citizen-focused urban policies (Garcia-Ramon and Albet, 2000; McNeill, 1999; Marshall, 2004). In the 2000s, however, the Barcelona Model underwent a transformation. In the context of the global fascination with the 'knowledge-based economy', and with the determinants of urban competitiveness in an ever more 'digital age', successive local governments pursued more entrepreneurial strategies in which the interests of global corporations, financiers and real estate developers seemed very clearly to eclipse those of the city's residents. This trajectory only seemed to be complete after 2011, when - in the context of a profound and protracted economic and social crisis the city's municipal government committed itself to making Barcelona the world's leading smart city (March and Ribera-Fumaz, 2016).
More recently, however, Barcelona has become a referent for a radically different vision of urban governance - as the quintessential 'rebel city' (Graham, 2018; Shea Baird, 2015). Under the leadership of the citizens' electoral platform Barcelona en Comú ('Barcelona in Common', henceforth BComú) since May 2015, the city's leadership has been touted by the international left as an example of the reinvigoration of municipal feminist-socialism in times of crisis, popular anxiety and the draw of rightwing populism (Russell, 2019; Shea Baird, 2017), and not merely in terms of its 'progressive local policies' in crucial areas such as housing and energy provision (Roth et al., 2018: 133; Rubio-Pueyo, 2017). Rather, it has also been heralded as a significant experiment in radical democracy (Gessen, 2018), in which the smart city agenda in particular is being fundamentally re-purposed for citizens through the advancement of the right to information and guarantees to open, transparent and participatory decision-making through new digital and platform technologies (Postill, 2016). For the critical smart city scholars Cardullo and Kitchin (2019: 11), Barcelona has today become the referent for 'presently attempting to formulate and implement a different vision of a smart city and smart citizenship', 
and for its attempt to 'repoliticise the smart city and to shift its creation and control away from private interests and the state toward grassroots, civic movements and social innovation' (original emphasis).

While the case of Barcelona may stand out from a range of other examples in which the corporate-friendly, technologically determinist and essentially neoliberal vision of urban transformation has been questioned (Hollands, 2015; March, 2018), we suggest that it is worthy of deeper critical reflection and elaboration. This, after all, is the intent of this special issue which, rather than focusing on the politics of 'actually existing' smart city projects, asks critical questions of dominant epistemological forms of knowing the smart city. In drawing upon the two approaches of 'worlding' and 'provincialising' to reflect on our own experiences of over a decade's worth of fieldwork in Barcelona (including interviews with activists and municipal department leaders, and participation in initiatives aimed at repurposing the smart city), our contribution explains how the Barcelona case evinces that:

worldings that emerge from subordinated experiences, cutting across distinctive loci of enunciation, can (indeed) be productive of alternative theoretical perspectives with the potential to speak back against those theories underwriting global urbanism, thereby decentring current geographies of knowledge and theory production. (Sheppard et al., 2013: 897; emphasis in original)

However, heeding the suspicion of any emergent urbanism that draws upon or makes 'universalist' claims, as well as the cautioning by Henri Lefebvre (a primary influence on Roy, 2011) against being uncritical of forms of 'urbanism of the left' (Lefebvre, 2003: 163), we also want to resist taking at face value the evidence that Barcelona's recent experience signals a straightforward sea change in the conceptualisation and practice of smart city transformation; from a corporate-driven, top-down model to a citizen-centric, bottom-up one.

Our contribution begins with a brief elaboration on what we find to be most instructive about the worlding and provincialising literatures, as well as some preliminary comments about why it is appropriate to adopt the 'rebel city' concept as a heuristic for reflection on the recent repurposing of the Barcelona Model of urban transformation. We then turn, in the second section, to reflect upon the version of the Model that was explicitly aligned with the theory and practice of smart city transformation before 2015. We do accept that this was an especially doctrinaire and dogmatic version, which explains to some extent why its subsequent repudiation by BComú has attracted so much attention (see, for instance, Kitchin et al., 2019). We also make clear, in the third section, that the 'actually existing' smart city in Barcelona was by 2015 already a product not only of worlding flows but also of a proliferation of socially innovative practices and forms of contentious politics within the city itself. Seen in this light, it becomes less easy to narrate the arrival of the BComú-led council and its citizen-focused agenda as a clean rupture with the smart city status quo ante. We then examine the content of two important initiatives that have been at the centre of the new municipal government's approach to repurposing digital technologies for the citizen under the rubric of democratic and participative 'techno-politics' and 'technological sovereignty'. We highlight the progressive intent of these projects, but conclude the discussion by posing critical questions of them.

\section{On worlding and provincialising the rebel city}

The two concepts of 'worlding' and 'provincialising' are gaining traction among 
researchers of planning, urbanism and urbanisation, while also being subject to multiple - and, at times, dissonant - interpretations, foregroundings and modes of analytical deployment (see the Introduction to this special issue). It is worth, therefore, us providing a brief explanation of what we find most relevant and instructive in the two literatures for our own research on the Barcelona Model.

Having previously drawn on the work of Henri Lefebvre in order to critique how representational models for knowledgebased urban transformation have been cultivated and operationalised in Barcelona, even before the advent of the smart city agenda (Charnock and Ribera-Fumaz, 2011), we are especially interested in how Roy (2011) also draws on Lefebvre to elaborate her own appraisal of how urban planning is implicated in the production of space; a process determined (but not wholly so) by capital accumulation, and mediated in large part by 'the signs and symbols deployed by experts as they seek to control and order space' (Roy, 2011: 8, 9). Roy highlights how experts' modelling increasingly relies on 'referenced urbanism' (see also McCann et al., 2013), which too often submits real places and labouring bodies to the violence of abstraction as soon as the concretisation of technocratically conceived planning models sets in motion the bulldozing and dispossessions too often associated with planned urbanisation (Roy, 2011: 10). ${ }^{1}$ But Roy also explains how the circulation of models is 'complex' and 'disjunctured': referencing can be both conformist and progressive in content; it can represent the results of urban transformations partially or selectively; and, consequently, it can provoke openings for debate about the questions 'who plans?' and 'for whom do they plan?' (Roy, 2011: 12). These questions are especially pertinent to the recent experience of the repurposing of the smart city agenda in Barcelona since
2015. Once criticised both for being 'overreferenced' among worlding urbanisms (McCann et al., 2013: 582), and also as the paragon of how strategic planning based on stridently entrepreneurial forms of urbanism leads to 'opportunities to pocket monopoly rents galore' and lures 'more and more homogenising multinational commodification in its wake' (Harvey, 2012: 104-105), this repurposed Barcelona Model now circulates as a referent for those looking for 'transformative political mobilisation to create ... a humanising urbanism' (Kitchin et al., 2019).

For Kitchin and other critical urban scholars, this new Barcelona Model of 'smart citizenship' offers a re-envisioning 'that seems more grounded in the hopes and politics of the "right to the city" agenda' (Kitchin et al., 2019: 17); an agenda influenced by another of Lefebvre's ideas (Lefebvre, 1996). While the worlding literatures together recognise that 'cities are rife with worlding projects, each vying to be realised and each having different chances of success' (Baker and Ruming, 2015: 66), the right to the city demand has become something of a rallying slogan for the new international municipalist movement (Gilmartin, 2018). This is understandable: focusing on the right to the city as an explicit 'horizon' might indeed 'clear a path', to use a couple of Lefebvre's most oft-used phrases, through the stifling and disjunctured melee of 'critical thought, reformist ideology, [and] leftist opposition' (Lefebvre, 2003: 161) induced by vying forms of urbanism. The problem, however, is that 'the right to the city is an empty signifier. Everything depends on who gets to fill it with meaning'; as such, 'it can never be an end in itself' (Harvey, 2012: xv, xviii). Critical urban scholars should, therefore, be attentive to how the right to the city rhetoric is endowed with meaning as it is adopted by circulating models; they should question, in particular, the opacity of the 
category 'citizenship' as it figures in various right to the city manifestos, especially when the rights attached to citizenship - and of 'smart citizenship' especially - sit all too easily with those of the productive and juridical subject upon which the reproduction of capital through production and exchange depends. ${ }^{2}$ In other words, it is always worth asking whether a worlding project claiming to advance the right to the city at least acknowledges the class relations between capital and labour inherent to in the production of space (even if it is also recognised that there are limits to what might be done to transform these relations at the local scale), as well as the struggle for reimagined forms of citizenship; and the intimate relationship between these two struggles. A city that adopted a project that went some way towards defining the right to the city in this way, and with it redefining the idea of the urban commons on the basis of the collective retention of value by those who produce it (Harvey, 2012: 87), would truly epitomise the 'rebel city'.

The provincialisation literature yields a further line of questioning worth asking of particular worlding projects, and even those that purport to re-centre and, to some extent, re-signify the meaning of citizenship. This questioning is focused not on the terms of citizenship, nor on the rights of capitalists to command the production and appropriation of value in the city, but on the political subjectivity of the citizen herself; more precisely, on the 'anthropological production' of that subjectivity (Dardot and Laval, 2017: 12) as digital technologies become so integral to everyday life and, importantly, as citizens exercise their claims to rights through the internet (Isin and Ruppert, 2015). Here, the problem can be initially posed in terms of whether and how citizens' digital rights are both inscribed and enacted in specific contexts. Smart citizenship projects, like those we allude to above, can certainly claim to inscribe rights, but by no means guarantee enactment on a universal and inclusive basis (Lemanski, 2019: 10). But even in contexts where there is a palpable and widespread zeal for such projects as distributing citizen sensing kits to monitor noise pollution, or for platform-enabled participatory democracy among citizens, a further question can be posed: does the use of digital platform technologies to 'include' citizens merely cultivate a form of governmentality, or 'smartmentality' (Vanolo, 2014), in which a great many citizens gain fulfilment from playing a functional role within the smart city while continuing about their erstwhile daily lives as entrepreneurial economic and docile political - subjects (Datta, 2018: 411-413)? In focusing on 'environmentality', or on 'governance through the milieu', Gabrys (2016: 191) certainly finds this to be a defining feature of a great many smart city design proposals, wherein 'participation involves computational responsiveness and is coextensive with actions of monitoring and managing one's relations to environments' (Gabrys, 2016: 196), and to the degree that such proposals rely on citizens as 'ambividuals: ambient and malleable urban operators that are expressions of computer environments' (Gabrys, 2016: 201).

In what follows, we want to pose similar questions of the Barcelona case; questions that resonate with a concern about leftist, circulating worlding projects that purport to reactivate citizens and their rights: namely, whether new techno-political imaginaries and practices necessarily guarantee relief from, or control over, the production of space (in which flows of capital play a determinate role); and whether they awaken among citizens a sense of their own productive and political subjectivity that runs counter to the reproduction of entrepreneurial, docile and ambividual conceptions of citizenship. 


\section{The apogee of smart urbanism in Barcelona: The ontologisation of the city}

As explained in more detail elsewhere (March and Ribera-Fumaz, 2018), the smart city imaginary was fully embraced by Barcelona's city council with the arrival of Mayor Xavier Trias, of the centre-right Convergència i Unió coalition, in 2011. This vision was characterised by a particularly insincere and vacuous notion of the citizen as a social constituent. The understanding of urbanism and planning as 'worlding practice' helps us to understand the degree to which the Trias administration saw fit to convert to and preach the smart city gospel, and the particular significance of the category of 'the citizen' within it. And Roy's (2011) recourse to the critical theory of Henri Lefebvre is instructive, here. Lefebvre deemed urbanism to be ideological precisely because it aspires (consciously or naively) to 'control the process of urbanisation and urban practice and subject [that process] to its order' (Lefebvre, 2003: 151). Lefebvre also expressed grave concern about what he termed 'information ideology' and those who would conceive of 'computerised daily life': the vision of an 'electronic Agora and the disturbing project of a technological extension of the "audit"... capable of being extended to political and police control of spaces much vaster than the enterprise' (Lefebvre, 2008: 148-149). As several other critical commentaries have argued, as a form of instrumental reason and 'computational urbanism' the imaginary of the smart city is especially ideological (Cugurullo, 2018; Marvin and Luque-Ayala, 2017). As an increasingly alluring and hegemonic form of urbanism, it has come to play an active role in the worlding of cities even while these ideologues ... refuse to concede they are presenting, or representing, a tendentious political project. To them, the project seems to follow logically from the technology' (Lefebvre, 2008: 149). Lefebvre gave this species of ideologue - enthralled by the power of robots, by 'the superiority of machines' and by the capacity of computers to learn autonomously from their environment and therefore to programme the urban - a name of its own: the cybernantrope (Lefebvre, 1972: 164-165).

If ever there were a vision of smart city transformation that portrayed its ideological character, it is that which came from within the Trias administration: 'We imagined the city as a mobile phone: why can't we have a city that works with an operating software based on standards that interact with the hardware (whatever it is) and software (any app)?' (Josep Ramon Ferrer, former director of Barcelona's smart city strategy, quoted in Carrasco et al., 2017: 1). The mobile phone, as Arboleda (2019) notes, is perhaps the 'flagship technological artefact of the fourth machine age'; it is, as Aschoff (2015) argues, 'both a machine and a commodity. Its production is a map of global power, logistics, and exploitation. Its use shapes and reflects the perpetual confrontation between the totalising drives of capital and the resistance of the rest of us.' Aside from the unfortunate association of the smart city with this artefact, the 'city as software' vision also encapsulates the somewhat 'cybernantropic' notion that urban processes can - and should - be ontologised. ${ }^{3}$ In urban settings, ontology engineering is said to be able to assist in the reconciliation of interoperability and cooperation issues between databases with urban information from different sources' (Martins et al., 2012: 507). The allure of rendering urban processes and data machine-processable is therefore enhanced once the 'data inoperability barrier' is transcended. That is, once any given city can be reduced to its most generic readable attributes, and on that basis can be subjected to surveillance and control by means of the 
collection and processing of information (Sadowski, 2017). As Lefebvre (2003: 161) notes, 'the urbanist amasses data and information'. The instrumental appeal of being able to read and control the city as a database is considerable, whether seen from a logistics, mobility, policing or environmental management point of view. Add to this the appeal of commercialising interoperable techniques of reading the city and it is unsurprising that city authorities and ICT corporations the world over have sought to co-develop and market different versions of an 'urban operating system', or Urban OS. As Marvin and Luque-Ayala (2017) have already observed, Urban OSs are generally built on exclusionary and depoliticising assumptions that foreclose exterior challenges to their ontology, and which are functionally resistant to exterior sources of innovation, creativity or problems that cannot be couched 'in the necessary language of data' (Shelton, 2017: 27).

One such example, not discussed by Marvin and Luque-Ayala, was the CityOS developed in Barcelona as a joint venture between the Trias administration and a handful of corporations (Accenture, Triada Telecom, Sinovia and Cofely España) and unveiled in April 2015, one month before the election of the BComú-led city council. It was formulated in accordance with the administration's bold vision that 'all of the cities of the world want to be the protagonist [of smart city transformation] ... a unique opportunity to apply solutions in which Barcelona can be the laboratory and the leader at the same time' (Ajuntament de Barcelona, 2012a: 3). As a form of ontology engineering, and much like other examples of representations of digital urbanism that reduce the city to a 'logistical exercise', CityOS suggests that the standardised city can be read and programmed irrespective of 'changing organisation, ownership or orientation' (Luque-Ayala and Marvin, 2016:
205): that is, in a thoroughly depoliticised form. In this, the citizen herself becomes a mere component of a taxonomised subsystem within a system: 'the citizen, rather than a political subject, becomes an operational component of the infrastructure' (LuqueAyala and Marvin, 2016: 205).

As noted above, the ontologisation of the smart city, with its focus on standardisation and interoperability, lends itself to marketability. To this end, and in addition to the development of CityOS, the Trias government had also made considerable inroads into positioning Barcelona as the prime international referent for smart city transformation through its leading role in the City Protocol Society: 'a delivery-focused network of global cities that, in partnership with industry, research agencies and other organisations', expressly sought to produce common technological and industry-based standards, technologies and solutions; 'recognised and certified projects and policies of reference for cities, tested in cities that can be used as examples for other cities'; and produced a database of indicators (Ajuntament de Barcelona, 2012b: 7). It sought, with 'worlding' intent, to make Barcelona the standard referent or model at the centre of a profitable endeavour to generate and circulate a standardised, interoperable ontology that could provide a 'common language' with which to describe the anatomy of a city (Flint, 2012), whatever and wherever the specific urban context.

By 2011, tangible investments in constructing new smart buildings and transport infrastructure, and installing cutting-edge energy-efficient smart water cooling and heating systems for the city's 22@ Knowledge District, had already attracted considerable international investment and recognition. Under the Trias administration, a range of additional concrete initiatives were undertaken to make Barcelona the world's leading smart city and, in the words 
of Barcelona's then-Chief Architect Vicente Guallart (2012: 31), an international referent for 'a new model of networked cities, with self-sufficient and productive neighbourhoods at human speed, within a hyperconnected zero emissions city'. Strategic changes in the municipal administration of infrastructure, housing and environment were quickly implemented, creating a single department - Hàbitat Urbà - charged with bringing city governance in line with ICTand internet-focused processes. ICT and internet topologies were made the key ordering principles of a smart city that would become the 'economic engine for the creation of wealth and welfare for its citizens' (Ajuntament de Barcelona, 2012a: 2). Contractual agreements were struck in 2012 with the likes of Cisco, Schneider Electric, Suez and Endesa to develop several local projects and pilots, principally in the areas of infrastructure, sensing and operation systems/software. Such was the additional progress made by the Trias administration by 2015 that, according to a Fortune report, Barcelona was 'the most wired city in the world' with a smart city agenda that, at that time, 'seemed unstoppable' (Walt, 2015).

The resulting 'actually existing' smart city project that was realised prior to 2015 was, however, just as characterised by 'local variety' as any other example that has been 'coproduced by its local, national and international context' and that has arisen through 'messy social, technical and political processes, rather than [being] determined by ... policy discourse' (Cowley and Caprotti, 2018: 429). It was, as Lefebvre might put it, a produced smart space: determined and mediated by multi-scalar, and contradictory, material and ideological flows, processes and forms. As with all forms of urbanism, the smart Barcelona Model was also necessarily characterised by important 'blind fields' in its comprehension of urban reality (Lefebvre, 2003; Roy, 2011). It failed to recognise the ubiquity and heterogeneity of different and differential representations of urban space and spatial practices, in the context of a deepening crisis of social reproduction.

\section{Provincialising smart urbanism in Barcelona}

Smart urbanism, we can safely assume, is as likely to be frustrated by contradictions - 'the power and radicality of the ragged and the irreducible' (Merrifield, 2009: 939) - and political struggles waged in provincial spaces over 'the way in which technique is used, who uses it, and for whom' (Lefebvre, 2008: 152) as any other form of urbanism. Even in the midst of the transformation of Barcelona from the 1990s until the advent of smart city investments, the city has always been a site of local resistance against - and experimentation with alternatives to - top-down, strategic urbanisation and the corollary processes of gentrification and speculative real estate development (for example, López Espinosa, 2016; Mansilla López, 2015; Pascual-Molinas and RiberaFumaz, 2009). The same was true for the period of smart city transformation instigated in earnest by the Trias administration after 2011; to the extent that by the end of the latter's tenure in office, the 'actually existing' smart city in Barcelona amounted to a complex array of those flagship public-private projects outlined above along with other notable alternative economy and digital social innovation initiatives instigated outside of the auspices of the city council and only subsequently co-opted or subsumed within the smart city Barcelona brand.

A study by Castells and Hlebik (2017: 162) attests to how, by 2011, Barcelona was already 'one of the most socially innovative urban environments in the world'. They document the extent to which there was an explosion of alternative and countercultural social exchange, food production 
and reproductive care practices within the city: 'embryos of a new economy, out of the necessity of replacing dysfunctional capitalism [and] also motivated by a search for a meaningful life' (Castells and Hlebik, 2017: 180). An 'ecosystem' of alternative economy and digital social innovation practices further thrived during the Trias years, ${ }^{4}$ and it is important to recognise that this was not always at odds with that city council's smart city vision. For instance, the council became partner in an EU-funded H2020 project, D-CENT, alongside local technopolitical activists from the indignados movement that had attracted so much international attention for leading mass public demonstrations against the political elite in Spain in 2011 (Charnock et al., 2012). It was this project that went on to develop the platform Decidim Barcelona, which is the technological cornerstone of the new municipal government's radical democratic programme (see below).

While social innovation experiments proliferated across the city after the onset of a profound recession after 2008, the city also witnessed dramatic forms of social movement protest. Notably, Barcelona-based activists formed the Platform for Those Affected by Mortgages (PAH) in 2009, and have since led the way in contesting the tidal wave of evictions in the wake of the crisis, saving thousands from homelessness and destitution - earning international recognition as human rights campaigners in the process. The PAH, as part of a broader indignados movement from 2011 onwards, reflected and, in turn, fomented a post-crisis revitalisation of community-scale 'insurgent practices' (García-Lamarca, 2017) that in the Barcelona case led to the momentous election in May 2015 of BComú to lead the city council. For Kaika (2017: 1280, 1285), who is generally quite critical of 'deeply affective but ultimately apolitical reactions to the crisis' across Europe, the unique example set by the PAH is that it 'enacts anti-evictions activism as a collective social practice, not a private affair'. 'In short', she suggests, 'the PAH actively promotes a process that not only re-houses, but also re-dignifies evicted citizens through a deep-seated process of politicisation that changes how citizens define themselves' (Kaika, 2017: 1286). And one might justifiably argue that BComú has remained true to the PAH's exemplary form of 'politics beyond affect' since its election in 2015. Within just a few months (as detailed in Charnock and Ribera-Fumaz, 2017: 194196), the new city council pledged to invest $€ 180$ million over an initial period of 18 months in quality jobs. In addition, it took an aggressive stance towards banks over the negotiations to halt evictions and to release vacant housing, among other initiatives to increase the stock of available social housing. It also committed to guarantees of food security for the city's children and adolescents; pledged to boost affordable means of public transport; experimented with universal income support for the poorest families in the municipality; and, under the campaign slogan 'energy is your right' (l'energia és el teu dret), made substantive moves towards guaranteeing energy security that almost immediately brought it into legal conflict with the largest Spanish energy providers. And it also opened up the possibility of the re-municipalisation of the urban water supply service.

BComú can therefore boast a radical pedigree and track record of considerable integrity and repute - especially as regards its prioritisation of the immediate and substantive needs and rights of those inhabitants most adversely affected by the economic crisis and its enduring fallout. Its inception as a political movement - with its roots in struggles over housing - can therefore be explained as a product of radical responses to the crisis, but also as a movement that brought together pre-existing experiments 


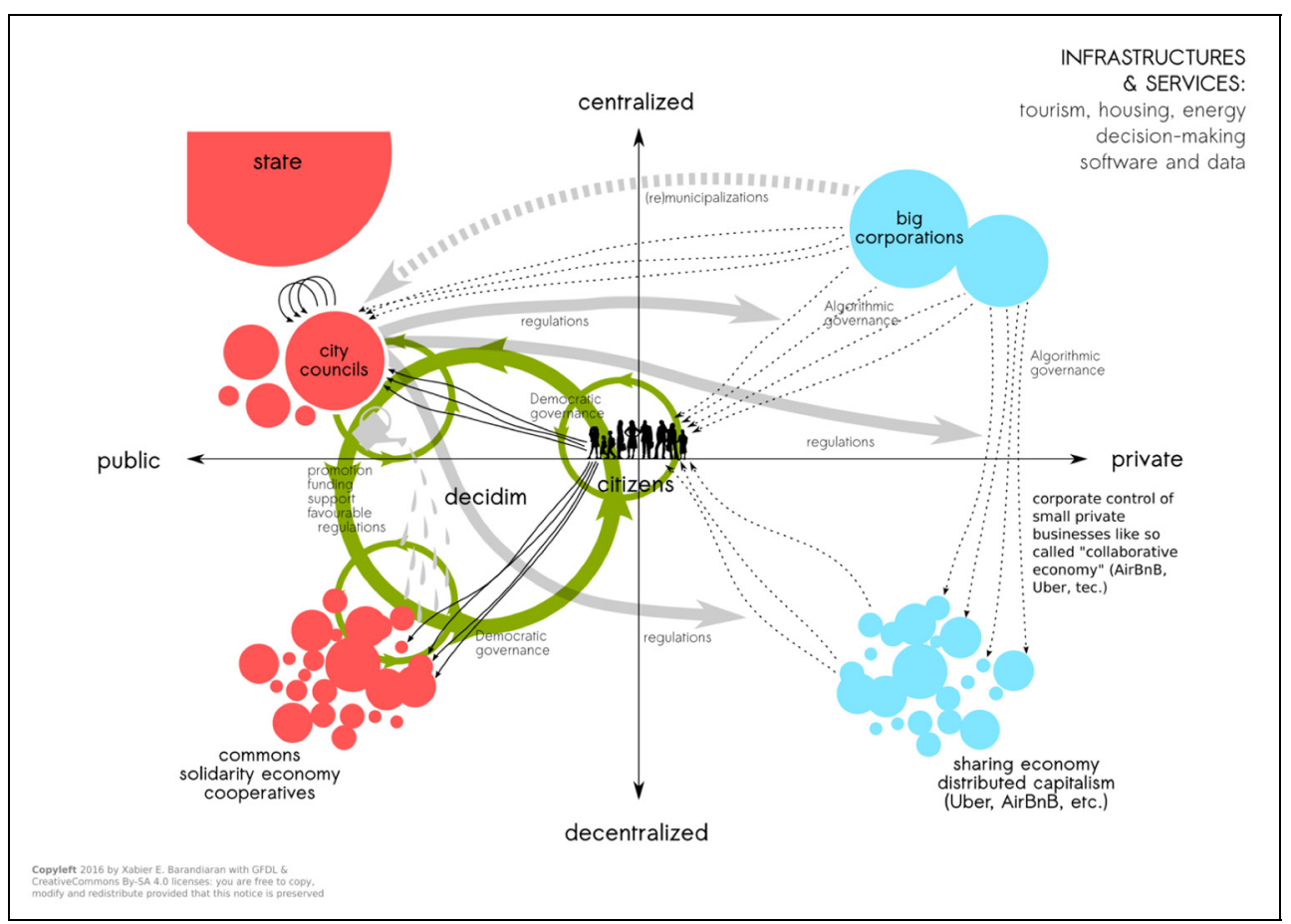

Figure I. What is Decidim?

and projects with digital technologies that were not necessarily at odds with the smart city imaginary espoused by the Trias administration. This raises the question, therefore, of the degree to which the BComú-led city council has since made inroads towards establishing a radically different vision of the relationship between institutions of urban governance, digital technologies and citizens. We now therefore turn to the content of the new municipal government's 'smart' policies.

\section{Digital democracy and technological sovereignty in the rebel smart city}

In addition to confronting a general crisis of social reproduction in the city through substantive and radical spending and social policies, BComú's government has committed itself to the radical technological overhaul of democratic processes so as to allow for the fullest possible degree of collective participation in decision-making - and on an ongoing, 'agile' basis. In particular, the Decidim Barcelona ('We Decide Barcelona') open-source platform for citizen engagement and input in areas like budgetary planning, which was launched in October 2015, has been greeted as:

a decentralisation of power that equips communities with the instruments to make decisions collectively ... To encourage the use of digital infrastructures that can be reappropriated and to ensure they can be accessible and that people can learn to use them. (Roth et al., 2018: 135)

For its architects, Decidim Barcelona is conceived as a means of 'empowering social processes as a platform for massive 
social coordination for collective action independently of public administrations' (Barandiaran, 2018; emphasis in original). ${ }^{5}$ It is a "technopolitical project" where legal, political, institutional, practical, social, educational, communicative, economic and epistemic codes merge together' (Barandiaran, 2018). Put more prosaically, Decidim Barcelona 'encourages the use of technology to facilitate an active democracy' (Morozov and Bria, 2018: 50), with citizens at its centre (see Figure 1). As of 1 March 2018, the platform had more than 28,000 registered participants and 19 participatory processes, and had facilitated 821 public meetings. This had resulted in 12,173 proposals - of which 8923 had been incorporated into public policy (Barandiaran, 2018). One notable result was the participative drafting of the 2013-2018 Urban Mobility Plan to reduce air and noise pollution, and the volume of city traffic by $21 \%$, through the construction of urban superblocks (superilles) which limit passage and accessibility for motor vehicles and which prioritise instead pedestrians' right to enjoy open, shared, green and safe public space. $^{6}$

In addition to harnessing digital technologies for participatory means, BComú has also sought to overhaul the top-down character of smart city governance in the city (Nesti, 2018: 13). In September 2016, the CiU-instigated contractual negotiations with Cisco and Schneider Electric to invest $€ 37$ million in a Smart City Campus were suspended by the BComú-led government, with Deputy Mayor Gerardo Pisarello openly stating that the 'logic behind the project' was one the new city government 'could not allow to continue' (Bolsamanía, 2016). Since then, the city council has invested in its own open source digital economy projects such as La Comunificadora (an incubator for collaborative economy start-ups), and it has launched a new public digital technologies procurement process that discriminates in favour of cooperatives and collaborative economy-based SMEs - terminating a contract with Microsoft in the process. In October 2016, the city council announced its Digital Transformation Plan, to which it allocated a total budget of $€ 72$ million. The Plan aims to 'revitalise the entire municipality, by consolidating the governance of digital services, by generating profiles and capabilities in free and open source software and the ethical use of data and by transforming public procurement' (Bria et al., 2017: 6). For the city's Chief Technology and Digital Innovation Officer, Francesca Bria, the Plan points to how the city council has 'reversed the [smart city] paradigm completely' (Bria, quoted in Tieman, 2017), and to the degree that Barcelona now represents an alternative to 'the surveillance capitalism from Silicon Valley, and the dystopian Chinese model' (Bria, quoted in Graham, 2018).

The alternative smart city model envisioned in the 2016 Plan has at its core the goal of 'technological sovereignty' (sobirania tecnologica, in Catalan): 'That means taking back control of data and information generated by digital technologies, and promoting public digital infrastructures based on free and open source software, open standards and open formats' (Bria, 2017). For its proponents, this represents a significant example of a broader political and geopolitical agenda to 'contest a privatised smart city constructed from the top down and favouring foreign corporations, oppose monopolised ownership of intellectual property, and reverse the private appropriation of collectively produced value by rent-seeking digital platforms' (Morozov and Bria, 2018: 27). More concretely, technological sovereignty implies a series of tangible benefits in the governance of the city: 'an end to the oligarchy of technology providers'; a 'review of contract frameworks to ensure data sovereignty'; the 'creation of crucial new capabilities in the public sector to regain control of 
digital services'; 'increased efficiency in terms of output and costs since $70 \%$ of investment in new software development will be free and open source with open licenses'; 'enhanced local collaboration with networks between cities and public administrations'; and 'enhanced access to data held by the Administration and guarantees for citizens' basic [data] rights' (Bria, 2017).

The plans to further develop the Decidim Barcelona platform, agile digital public service delivery and the technological sovereignty agenda are expressly antiestablishment and anti-corporate. They do indeed push back against dominant forms of urbanism, ideology and knowledge to enunciate alternative theoretical understandings, and do so by also claiming to advance the perspective of the subordinated local population and to defend their interest. As such, they are provincialising in intent; they concentrate the goals of a wider grassroots movement in Barcelona advocating 'alternative modes of digital development in urban life' (Lynch, 2019: 1). Yet these plans are also worlding in intent: the technologists and activists behind Barcelona's new model are 'actively cultivating and tactically engaging' their own global imaginary for digital technology-enabled urban democracy and planning 'from below' (to paraphrase Baker and Ruming, 2015: 66). ${ }^{7}$ They are ambitious enough to aspire to setting an example for a global network of rebel smart cities, generating interoperable participative digital platforms for other municipalities and contributing to the development of a new Barcelona Model: 'Barcelona is positioning itself as a reference example in open digital transformation ... Barcelona is one of the first cities in the world to present an holistic framework at a municipal level' (Bria, 2017). It is testament to this ambition that Barcelona, together with Amsterdam and New York City, initiated the Cities Coalition for Digital Rights in November
2018; a coalition supported by the UNHabitat programme and currently comprising over 25 cities, which has 'defined a set of digital ethical standards and policy guidelines that are now shared among cities' as 'the foundations for a people-centric digital future' (Bria, quoted in Cities for Digital Rights, n.d.).

But the question is whether the plans initiated by the post-2015 city council carry the potential to transform the legacy not only of the especially dogmatic smart urbanism of the Trias administration, but of the more fundamental relation between the different worlding flows that together comprise, on the one hand, the city as an urban process and, on the other hand, the demands of citizens as necessarily situated political subjects, and the process of reconciling the essentially contradictory relationship between these two by means of mediation by municipal institutions. The final section of this contribution poses open questions of this agenda to repoliticise and repurpose the digital technologies at its disposal for 'the citizen'.

\section{The challenge ahead: Citizenship, technology and subjectivity}

Harvey (2008: 23) argues that 'the right to the city is far more than the individual liberty to access urban resources: it is a right to change ourselves by changing the city'. For his part, Lefebvre understood that the demand for the right to the city could not be reduced to the demands of an 'unreal universality' on the part of the rights-bearing citizen: 'the rights of the citizen are abstract, fictitious' (Lefebvre, 2009a: 75). ${ }^{8}$ Elsewhere, he asserted that it would be naïve to assume that machines and technology could be put to use to realise the possibilities of generalised self-management (autogestion) without a fundamental revolution in 'the expression of social needs and the social control of production' (Lefebvre, 2009b: 151). What these 
prototypical critics of worlding urbanisms both recognise is that 'the citizen' may well constitute the fundamental subject of any urban revolution, but that this 'citizen' will possess a specific form of subjectivity conscious of its own necessarily social power (as opposed to the limited transformative capacity of the passive 'private' citizen identified by Kaika, 2017). This citizen is committed to the collective overhaul not just of democratic processes of decision-making but of forms of social production and reproduction, and the repurposing not simply of technological governance but of the urban process itself, on a networked, global scale; to rebelling, in other words, against the law of value (Harvey, 2012: 153).

As we have seen, above, the BComú-led municipal government's agenda represents a concerted effort to break with the legacy of top-down governance after almost 40 years of Socialist and - briefly - CiU rule, and to 'win back Barcelona' for its citizens and for the 'common good' (Charnock and RiberaFumaz, 2017). Some have interpreted this agenda as a welcome return to a citizenfocused and broadly redistributive approach to urban governance characteristic of the early Barcelona Model of the late 1980s and early 1990s (Eizaguirre et al., 2017). Yet this nostalgic interpretation is precisely based upon an abstract and 'unreal' conception of the citizen-as-subject. The notion that successive city councils in Barcelona have established relations with citizens which are more or less 'inclusive' reduces the citizen herself to a mere formal abstraction or personification in which - in a perfect world - 'everybody is equal before the law and, as equals, all are treated identically as abstract citizens endowed with standardised rights' (Bonefeld, 2003: 206). As such, the debate on the smart city in particular is then usually framed in terms of whether it promotes an 'individual-liberal citizenship regime', a 'civic-republican citizenship regime' or some compromise between the two (Joss et al., 2017). As noted in the first section of this article, the provincialisation literature on the smart city also warns us against such formal conceptualisations of political subjectivity. Moreover, this view fails to acknowledge the argument already made by other critical scholars concerning the construction of the citizen-as-subject at the heart of the early Barcelona Model specifically. For Balibrea (2017), for instance, it was precisely during the city's hosting of the 1992 Olympic Games when 'the volunteer' came to represent the archetypal entrepreneurial subject of a 'bio-politics of urban branding' (Balibrea, 2017: 32) that resulted in Barcelona's 'specialism' as a global referent: namely, the production of 'neoliberal subjectivity itself' (Balibrea, 2017: 9). ${ }^{9}$

In other words, a question of fundamental political importance that is yet to be asked of the repoliticisation of the smart city in Barcelona is whether it is indeed carrying forward the 'politics beyond affect' Kaika deems to be characteristic of the $\mathrm{PAH}$, and is thereby engendering new forms of subjectivity among citizens themselves. Too much of the commentary on Barcelona's recent transformation from smart city to rebel city fails to recognise how, for citizens subject to worlding flows (Roy, 2011), "“work on the self" (praxis) and "labour" (production) combine' (Lazzarato, 2014: 51). That is, they leave aside the possibility that 'economic activity and the ethico-political activity of producing the subject go hand in hand' (Lazzarato, 2012: 39), and in such a way as to not only explain an explosion of insurgent practices in the context of a crisis of 'labour' and social reproduction, but also to implicate citizens' own 'praxis' in the coproduction of worlding processes that perpetuate the exploitation and alienation characteristic of the contemporary urban condition; however 'included' they might be in a formal, procedural sense. Put another 
way, the question is whether the repurposing of the smart city agenda under BComú carries the potentiality to engender alternative forms of subjectivity that go beyond the 'idiotic' politics of affect characteristic of an essentially depoliticised citizenry appropriate to neoliberal forms of bio-politics (Kaika, 2017). ${ }^{10}$

The conceptualisation of the citizen at the heart of contemporary movements, such as BComú, has already been the object of critique by Barcelona-based anthropologist Manuel Delgado. For him, the new 'citizenism' (ciudadanismo) elevates the 'abstract individual' to 'her maximum level of symbolic efficacy as a conceptual person' (Delgado, 2016: 12), a signifier emptied of real social determination (Delgado, 2016: 14). He asserts:

[... C]itizenism is, today, the result of a process of the regeneration of social democracy and of the liberal left ... Without doubt, it is a new pseudo-ideological paradigm through which the capitalist system aspires to suggest that it can be more humane and, to that end, channels and makes 'reasonable' the conflictive fractions of society by transforming them into 'social movements'. [These are] alien and even hostile to anything that evokes the struggles between classes. [They are] flows of collective action undertaken by isolated individuals that strive together to have a good time and who, sooner or later, will be invited to 'participate': that is, to be accomplices in their own domination. (Delgado, 2016: 16)

It is debatable as to whether Delgado's cynicism is warranted. Yet, it is the case that much of the justification for the radical overhaul of the use of new digital and smart technologies in the city appears to accept uncritically two fundamental postulates that suggest that Delgado's criticisms are not wholly unfounded. First, the notion that democratic participation is an intrinsically beneficent activity - especially when it is mediated by technologies perceived to be essentially 'neutral' in nature. ${ }^{11}$ In the 'new technopolitical grammar' of Decidim Barcelona's architects (Barandiaran and Calleja-López, 2016: 34), for instance, the technology is 'a reflexive infrastructure that uses the very infrastructure to democratise itself' (Barandiaran, 2018). The irony is that the goal here appears to be nothing less than the ontological engineering of democracy itself (Barandiaran et al., 2017: 140). To the degree that this agenda - typified in BComú's strategy for digital democracy - is critical, it is only to stress that the democratic potential of platform technologies will be limited unless the ownership and openness of the technology is guaranteed by a new 'social contract' on data. Otherwise, and second, it appears to assume the citizen - and social movements more generally - to be essentially incorruptible, on the one hand, and ultimately acquiescent in the containment of her interests and aspirations within agile democratic procedures for the production of consensus, on the other. In the case of Barcelona, it is not unreasonable to ask the architects of BComú's new agenda for digital democracy to what extent it addresses the bio-political legacy of decades of urban entrepreneurialism on the subjectivity of the citizen herself. $^{12}$ How, for instance, might digital democracy in itself militate against city halls present or future using citizens' zeal for participation in sensing, planning and governance to brand 'smart citizenship' for bio-political, urban-entrepreneurial ends once again?

\section{Conclusion}

For us, another particularly useful dimension of the provincialising urban theory approach is in its questioning of monist forms of knowledge, 'that is, a knowledge claim that becomes accepted as the only plausible account of a phenomenon', with the aim of 'disrupting norms about what we think we 
know' (Leitner and Sheppard, 2015: 230). Of course, the main targets of the provincialising literature (at least in Leitner and Sheppard, 2015; Sheppard et al., 2013) are those 'master narrative' forms of mainstream global urbanism that are conspicuously universalist (worlding), orientalising and wedded to the methodological and epistemological fundamentals of neoclassical economic theory. But, presumably, provincialising critique ought also to be wary of emergent forms of knowledge that, while appearing to reflect a common experience of disaffected and disenfranchised subjects in specific urban contexts, purport to speak back against hegemonic urbanism and for the subaltern in general. That is, in ways which seek to legitimise 'rebel' knowledges of urbanity, while nonetheless also aspiring to travel as a model for left urbanism. We have argued that some of what the new municipalist city council is trying to initiate with the repurposing of new digital technologies has been couched in specific left-theoretical understandings that postulate the essential beneficence of technodemocracy and leave unquestioned citizens' own productive and political subjectivities, irrespective of their own 'situatedness'. This implies that while Barcelona's newfound status as the rebel smart city is richly deserved, and its government's genuine commitment to addressing immediate social needs should not be doubted, it is still worth maintaining a diligently critical eye on its continuing transformation.

\section{Declaration of conflicting interests}

The author(s) declared no potential conflicts of interest with respect to the research, authorship, and/or publication of this article.

\section{Funding}

The author(s) received no financial support for the research, authorship, and/or publication of this article.

\section{ORCID iD}

Greig Charnock (D) https://orcid.org/0000-00030625-264X

\section{Notes}

1. To this, we would add the indirect gentrification and displacement processes associated with the speculative treatment of land and real estate as a financial asset in anticipation of new flows of urban rents arising out of regeneration and smart city projects (see Charnock et al., 2014).

2. See, for example, how the 'right to the (smart) city' tagline (el dret a la ciutat (intel-ligent) in Catalan) was used by Barcelona city council at the Smart City Expo World Congress 2018 to brand not only its commitment to digital rights, but also a range of initiatives from citizen sensing kits, to bike-sharing systems, to customer loyalty schemes in local commercial and food markets (Barcelona.cat, 2018).

3. In computer science, 'ontology is a technical term denoting an artefact that is designed for a purpose, which is to enable the modelling of knowledge about some domain, real or imagined'; while 'ontology engineering is concerned with making representational choices that capture the relevant distinctions of a domain at the highest level of abstraction while still being as clear as possible about the meanings of terms' (Gruber, 2009, emphasis in original). The point of ontology engineering, then, is to generate formal conceptualisations of given entities, so that they can be taxonomically organised within machine-readable and machine-processable data structures (Guarino et al., 2009; Métral et al., 2007). For critical comments on information technology, technique and 'objectivity’, see Lefebvre (2008: 146-153). In critical theory terms, the instrumental impulse to ontologise the social is to be treated with the utmost suspicion (Bonefeld, 2016; Lefebvre, 2016).

4. Cámara-Menoyo (2018) recounts 29 'urban commons' initiatives in the city between 2011 and 2015, ranging from the reappropriation of public space and buildings 
of significant historical memory (Espai Germanetes, Calàbria 66, La Flor de Maig, Espai Gardenyes, Hort Aspanias), to the defence of property, housing and public space against speculation, gentrification and the impact of mass tourism (Defensem Port Vell, Fem Rambla, La Borda, Asamblea de barrios por un turismo sostenible), and to the promotion of participatory urban planning and governance (Quina Gràcia, Decidim Barcelona).

5. Elsewhere, it is described as 'demo-technopolitics' (Barandiaran and Calleja-López, 2016).

6. See Barcelona.cat (n.d.); see also Vox's (2019) five-part series on the superblocks.

7. See also Russell (2019), who highlights the effectiveness of BComú's own International Committee in situating the platform as a flagship for a new, global and collaborative municipalist movement with the prefigurative potential to transcend the 'local trap'.

8. Lefebvre knew that the rights of the citizen are, at the same time, the rights that guarantee the double freedom of the producer; the 'freedom' upon which capital's own existence and self-valorisation is premised.

9. What really caught the eye of the European social-democratic left, back then, was the example Barcelona set for 'a re-invented municipal socialism, aware of globalisation, willing to work in partnership with the private sector' in its mission to regenerate the city and to revitalise public space (McNeill, 1999: 10). This strategy, synonymous with the 'new urban realism' espoused by the Socialist Mayor of Barcelona from 1982 to 1997, Pasqual Maragall, projected the city 'as a strategic space to be controlled'; 'multiclass, a space for citizenship as a basis of identity, rather than being bourgeois or proletarian ... [and] tied in with the Left's search for new social constituencies' (McNeill, 1999: 108, emphasis in original). For critics like Balibrea (2017) and Illas (2012), a closer inspection of the relation between the city council and citizens in that period reveals how 'control was implemented through agreement and cooperation', experienced as a feeling of 'collective euphoria' among many Barcelonans that functioned politically to quell dissensus regarding substantive, 'structural' issues: 'Consensus was generated from below, so to speak, and this made it all the more difficult for grassroots tactics or popular movements to contest these municipal politics' (Illas, 2012: 158159).

10. Morozov and Bria (2018: 20) also recognise the danger of digital technologies being used to unlock citizens' full entrepreneurial potential, with 'the use of communitarian rhetoric to justify offloading even more social responsibilities onto individual citizens'.

11. For a discussion of the essentially nonneutral nature of technological change in capitalism, see Arboleda (2016) and Smith (2010).

12. Not least, for example, when significant numbers of Barcelona's citizens are turning to platforms like Airbnb to profit from offering their own homes and properties as short-term rentals for the city's booming tourism market (Arias Sans and Quaglieri Domínguez, 2016). (At the time of writing, there are 18,346 listings in Barcelona, according to data from Inside Airbnb, n.d.). See Stabrowski (2017) for a discussion of how Airbnb, and the 'sharing economy' more generally, is producing 'urban microentrepreneurial' subjects.

\section{References}

Ajuntament de Barcelona (2012a) Mesura de Govern MES: L'estratègia TIC de l'Ajuntament de Barcelona al servei de la ciutat $i$ dels ciutadans. Barcelona: Ajuntament de Barcelona.

Ajuntament de Barcelona (2012b) Barcelona Smart City Tour. Barcelona: Ajuntament de Barcelona.

Arboleda M (2016) Revitalizing science and technology studies: A Marxian critique of morethan-human geographies. Environment and Planning D: Society and Space 35(2): 360-378.

Arboleda M (2019) Planetary Mine: Territories of Extraction in the Fourth Machine Age. London: Verso.

Arias Sans A and Quaglieri Domínguez A (2016) Unravelling Airbnb: Urban perspectives from 
Barcelona. In: Russo AP and Richards G (eds) Reinventing the Local in Tourism. Bristol: Channel View Publications, pp. 209-228.

Aschoff NM (2015) The Smartphone Society. Jacobin, 17 March. Available at: https:// www.jacobinmag.com/2015/03/smartphoneusage-technology-aschoff (accessed 14 June 2018).

Baker T and Ruming K (2015) Making 'global Sydney': Spatial imaginaries, worlding and strategic plans. International Journal of Urban and Regional Research 39(1): 62-78.

Balibrea MP (2017) The Global Cultural Capital: Addressing the Citizen and Producing the City in Barcelona. London: Palgrave Macmillan.

Barandiaran XE (2018) What is Decidim? Available at: https://xabier.barandiaran.net/2018/ 04/24/what-is-decidim/ (accessed 19 July 2018).

Barandiaran XE and Calleja-López A (2016) Plan estratégico para la Direcció de Recerca, Desenvolupament i Innovació de Participació. Barcelona: Ajuntament de Barcelona.

Barandiaran X, Calleja-López A, Monterde A, et al. (2017) Decidim: Redes políticas y tecnopolíticas para la democracia participativa. Recerca, Revista de Pensament i Anàlisi 21: 137-150.

Barcelona.cat (2018) El dret a la ciutat (intel-ligent). YouTube, 5 December. Available at: https://www.youtube.com/watch?v = I8utvTbl Ev0 (accessed 4 February 2019).

Barcelona.cat (n.d.) Superilles. Available at: http://ajuntament.barcelona.cat/superilles/es (accessed 26 April 2019).

Bolsamanía (2016) Colau frena una inversión de 36 milliones de euros en Barcelona. Bolsamanía, 13 September. Available at: https:// www.bolsamania.com/noticias/politica/colaufrena-una-inversion-de-37-millones-de-eurosen-barcelona-1706614.html (accessed 26 July 2018).

Bonefeld W (2003) The capitalist state: Illusion and critique. In: Bonefeld W (ed.) Revolutionary Writing: Common Sense Essays in PostPolitical Politics. New York: Autonomedia, pp. 201-218.

Bonefeld W (2016) Negative dialectics and the critique of economic objectivity. History of the Human Sciences 29(2): 60-76.
Bria F (2017) Barcelona digital government: Open, agile and participatory. Barcelona Digital City Blog. Available at: https://ajunta ment.barcelona.cat/digital/en/blog/barcelonadigital-government-open-agile-and-participa tory (accessed 19 July 2018).

Bria F, Rodríguez P, Bain M, et al. (2017) Barcelona City Council Digital Plan: A Government Measure for Open Digitization: Free Software and Agile Development of Public Administration Services. Barcelona: Ajuntament de Barcelona.

Cámara-Menoyo C (2018) Comunes urbanos: Lecciones desde la Barcelona de principios del siglo $X X I$. PhD Thesis, Universitat Oberta de Catalunya, Spain.

Cardullo P and Kitchin R (2019) Being a 'citizen' in the smart city: Up and down the scaffold of smart city participation in Dublin, Ireland. GeoJournal 84(1): 1-13.

Carrasco C, Ricart JE and Berrone P (2017) Barcelona: A roman village becoming a smart city. Caso SM-1646-E, 8 February. Barcelona: IESE Business School.

Castells M and Hlebik S (2017) Alternative economic practices in Barcelona: Surviving the crisis, reinventing life. In: Castells $\mathrm{M}$ (ed.) Another Economy Is Possible: Culture and Economy in a Time of Crisis. Cambridge: Polity Press, pp. 160-186.

Charnock G and Ribera-Fumaz R (2011) 'A new space for knowledge and people'? Henri Lefebvre, representations of space, and the production of '22@Barcelona'. Environment and Planning D: Society and Space 29(3): 613-632.

Charnock G and Ribera-Fumaz R (2017) Barcelona en Comú: Urban democracy and the 'common good'. In: Panitch L and Albo G (eds) Socialist Register 2018: Rethinking Democracy. London: Merlin Press, pp. 188-201.

Charnock G, Purcell T and Ribera-Fumaz R (2012) iIndignate! The 2011 popular protests and the limits to democracy in Spain. Capital \& Class 36(1): 3-11.

Charnock $\mathrm{G}$, Purcell $\mathrm{T}$ and Ribera-Fumaz $\mathrm{R}$ (2014) City of rents: The limits to the Barcelona model of urban competitiveness. International Journal of Urban and Regional Research 38(1): 198-217. 
Cities for Digital Rights (n.d.) New York City, Amsterdam, and Barcelona launch global coalition to protect digital rights. Press release. Available at: https://citiesfordigitalrights.org/ assets/NYC-AMS-BCN-LaunchGlobalCoali tionToProtectDigitalRights.pdf (accessed 24 April 2019).

Cowley R and Caprotti F (2018) Smart city as anti-planning in the UK. Environment and Planning D: Society and Space 37(3): 428-448.

Cugurullo F (2018) The origin of the smart city imaginary: From the dawn of modernity to the eclipse of reason. In: Linder C and Meissner $\mathrm{M}$ (eds) The Routledge Companion to Urban Imaginaries. London: Routledge, pp. 113-124.

Dardot P and Laval C (2017) The New Way of the World: On Neoliberal Society. London: Verso.

Datta A (2018) The digital turn in postcolonial urbanism: Smart citizenship in the making of India's 100 smart cities. Transactions of the Institute of British Geographers 43: 405-419.

Delgado M (2016) Ciudadanismo: La reforma ética y estética del capitalismo. Madrid: Catarata.

Eizaguirre S, Pradel-Miquel $\mathrm{M}$ and García $\mathrm{M}$ (2017) Citizenship practices and democratic governance: 'Barcelona en Comú' as an urban citizenship confluence promoting a new policy agenda. Citizenship Studies 21(4): 425-439.

Flint A (2012) Writing the rules for smart cities. Citylab, 23 July. Available at: https://www.ci tylab.com/equity/2012/07/writing-rules-smartcities/2663/ (accessed 16 August 2018).

Gabrys J (2016) Program Earth: Environmental Sensing Technology and the Making of a Computational Planet. Minneapolis, MN: University of Minnesota Press.

García-Lamarca M (2017) From occupying plazas to recuperating housing: Insurgent practices in Spain. International Journal of Urban and Regional Research 41(1): 37-53.

Garcia-Ramon MD and Albet A (2000) PreOlympic and post-Olympic Barcelona: A 'model' for urban regeneration today? Environment and Planning A: Economy and Space 32(8): 1331-1334.

Gessen M (2018) Barcelona's experiment in radical democracy. The New Yorker, 6 August. Available at: https://www.newyorker.com/ news/our-columnists/barcelonas-experiment-in -radical-democracy (accessed 10 August 2018).

Gilmartin E (2018) The mayors and the movements. Jacobin, 19 October. Available at: https://www.jacobinmag.com/2018/10/fearlesscities-review-ada-colau (accessed 26 April 2019).

Graham T (2018) Barcelona is leading the fightback against smart city surveillance. Wired, 18 May. Available at: http://www.wired.co.uk/ article/barcelona-decidim-ada-colau-francescabria-decode (accessed 5 June 2018).

Gruber T (2009) Ontology. In: Liu L and Tamer Özsu M (eds) Encyclopedia of Database Systems. New York: Springer-Verlag, pp. 19631965.

Guallart V (2012) La ciudad autosuficiente: Habitar en la sociedad de la información. Barcelona: RBA.

Guarino N, Oberle D and Staab S (2009) What is an ontology? In: Staab S and Studer R (eds) Handbook on Ontologies. Berlin and Heidelberg: Springer-Verlag, pp. 1-17.

Harvey D (2008) The right to the city. New Left Review 53: 23-40.

Harvey D (2012) Rebel Cities: From the Right to the City to the Urban Revolution. London: Verso.

Hollands R (2015) Critical interventions into the corporate smart city. Cambridge Journal of Regions, Economy and Society 8(1): 61-77.

Illas E (2012) Thinking Barcelona: Ideologies of a Global City. Liverpool: Liverpool University Press.

Inside Airbnb (n.d.) Barcelona. Available at: http://insideairbnb.com/barcelona/ (accessed 21 March 2019).

Isin E and Ruppert E (2015) Being Digital Citizens. London: Rowman \& Littlefield International.

Joss S, Cook M and Dayot Y (2017) Smart cities: Towards a new citizenship Regime? A discourse analysis of the British smart city standard. Journal of Urban Technology 24(4): 29-49.

Kaika M (2017) Between compassion and racism: How the biopolitics of neoliberal welfare turns citizens into affective 'idiots'. European Planning Studies 25(8): 1275-1291. 
Kitchin R, Cardullo P and Di Feliciantonio C (2019) Citizenship, justice and the right to the smart city. In: Cardullo P, Di Feliciantonio C and Kitchin R (eds) The Right to the Smart City. Bingley: Emerald, pp. 1-24.

Lazzarato M (2012) The Making of Indebted Man: An Essay on the Neoliberal Condition. Los Angeles, CA: Semiotext(e).

Lazzarato M (2014) Signs and Machines: Capitalism and the Production of Subjectivity. Los Angeles, CA: Semiotext(e).

Lefebvre H (1972) Contra los tecnócratas. Buenos Aires: Granica editor.

Lefebvre H (1996) Writings on Cities. Edited by E Kaufman and E Lebas. Oxford: Blackwell.

Lefebvre H (2003) The Urban Revolution. Minneapolis, MN: University of Minnesota Press.

Lefebvre H (2008) Critique of Everyday Life, Volume 3: From Modernity to Modernism. London: Verso.

Lefebvre H (2009a) The withering away of the state: The sources of Marxist-Leninist state theory. In: Brenner N and Elden S (eds) State, Space, World: Selected Essays by Henri Lefebvre. Minneapolis, MN: University of Minnesota Press, pp. 69-94.

Lefebvre H (2009b) Theoretical problems of Autogestion. In: Brenner N and Elden S (eds) State, Space, World: Selected Essays Henri Lefebvre. Minneapolis, MN: University of Minnesota Press, pp. 138-152.

Lefebvre H (2016) Metaphilosophy. London: Verso.

Leitner H and Sheppard E (2015) Provincializing critical urban theory: Extending the ecosystem of possibilities. International Journal of Urban and Regional Research 40(1): 228-235.

Lemanski C (2019) Infrastructural citizenship: Spaces of living in Cape Town, South Africa. In: Lemanski C (ed.) Citizenship and Infrastructure: Practices and Identities of Citizens and the State. London: Routledge, pp. 8-21.

López Espinosa A (2016) La construcción de los barrios democráticos en Barcelona: La dialéctica entre el movimiento vecinal en Poble-sec y Monjuïc a las instituciones municipales (19792011). In: Aricó G, Mansilla JA and Stanchieri ML (eds) Barrios corsarios: Memoria histórica, luchas urbanas y cambio social en los márgenes de la ciudad neoliberal. Barcelona: Pol-len Edicions, pp. 37-56.

Luque-Ayala A and Marvin S (2016) The maintenance of urban circulation: An operational logic of infrastructural control. Environment and Planning D: Society and Space 34(2): 191-208.

Lynch CR (2019) Contesting digital futures: Urban politics, alternative economies, and the movement for technological sovereignty in Barcelona. Antipode. Epub ahead of print 12 March 2019. DOI: 10.1111/anti.12522.

McCann E, Roy A and Ward K (2013) Urban pulse - assembling/worlding cities. Urban Geography 34(5): 581-589.

McNeill D (1999) Urban Change and the European Left: Tales from the New Barcelona. London: Routledge.

Mansilla López JA (2015) El triunfo de las clases medias: Dialéctica entre cambio social y urbanismo en Poblenou, Barcelona. Revista de Antropología Experimental 15: 121-139.

March H (2018) The smart city and other ICTled techno imaginaries: Any room for dialogue with Degrowth? Journal of Cleaner Production 197: 1694-1703.

March H and Ribera-Fumaz R (2016) Smart contradictions: The politics of making Barcelona a self-sufficient city. European Urban and Regional Studies 23(4): 816-830.

March H and Ribera-Fumaz R (2018) Barcelona: From corporate smart city to technological sovereignty. In: Karvonen A, Cugurullo F and Caprotti F (eds) Inside Smart Cities: Place, Politics and Urban Innovation. London: Routledge, pp. 229-242.

Marshall T (2004) Introduction. In: Marshall T (ed.) Transforming Barcelona. London: Routledge, pp. 1-24.

Martins T, Siliva PB, Coelho A, et al. (2012) An urban ontology to generate collaborative virtual environments for municipal planning and management. In: Proceedings of the International Conference on Computer Graphics Theory and Applications (GRAPP-2012), pp. 507510. Setúbal: SCITEPRESS.

Marvin S and Luque-Ayala A (2017) Urban operating systems: Diagramming the city. International Journal of Urban and Regional Research 41(1): 84-103. 
Merrifield A (2009) Review essay. The whole and the rest: Remi Hess and les lefebvriens français. Environment and Planning D: Society and Space 27: 936-949.

Métral C, Falquet G and Vonlathen M (2007) An ontology-based model for urban planning communication. In: Teller J, Lee JR and Roussey C (eds) Ontologies for Urban Development. Berlin: Springer-Verlag, pp. 61-72.

Morozov E and Bria F (2018) Rethinking the Smart City: Democratizing Urban Technology. New York: Rosa Luxemburg Stiftung.

Nesti G (2018) Defining and assessing the transformational nature of smart city governance: Insights from four European cases. International Review of Administrative Sciences. Epub ahead of print 3 April 2018. DOI: 10.1177/ 0020852318757063.

Pascual-Molinas N and Ribera-Fumaz R (2009) Retail gentrification in Ciutat Vella, Barcelona. In: Porter L and Shaw K (eds) Whose Urban Renaissance? An International Comparison of Urban Regeneration Strategies. London: Routledge, pp. 194-204.

Postill J (2016) Freedom technologists and the future of global justice. In: Buxton $\mathrm{N}$ and Eade D (eds) State of Power 2016: Democracy, Sovereignty and Resistance. Amsterdam: Transnational Institute, pp. 147-163.

Roth L, Lander B and Pin G (2018) Democracia radical en el Ayuntamiento. In: Ciudades sin miedo (ed.) Ciudades sin miedo: Guía del movimiento municipalista global. Barcelona: Icaria, pp. 113-121.

Roy A (2011) Urbanisms, worlding practices and the theory of planning. Planning Theory 10(1): 6-15.

Rubio-Pueyo V (2017) Municipalism in Spain: From Barcelona to Madrid, and Beyond. New York: Rosa Luxemburg Stiftung.

Russell B (2019) Beyond the local trap: New municipalism and the rise of fearless cities. Antipode 51(3): 989-1010.

Sadowski J (2017) Access denied: Snapshots of exclusion and enforcement in the smart city. In: Shaw J and Graham M (eds) Our Digital
Rights to the City. London: Meatspace Press, pp. 6-11.

Shea Baird K (2015) Rebel cities: The citizen platforms in power. Red Pepper, 17 December. Available at: https://www.redpepper.org.uk/ rebel-cities-the-citizen-platforms-in-power/ (accessed 16 July 2018).

Shea Baird K (2017) A new international municipalist movement is on the rise - from small victories to global alternatives. OpenDemocracy, 7 June. Available at: https://www.open democracy.net/can-europe-make-it/kate-sheabaird/new-international-municipalist-moveme nt-is-on-rise-from-small-vic (accessed 16 July 2018).

Shelton T (2017) Re-politicizing data. In: Shaw J and Graham M (eds) Our Digital Rights to the City. London: Meatspace Press, pp. 24-27.

Sheppard E, Leitner H and Maringanti A (2013) Provincializing global urbanism: A manifesto. Urban Geography 34(7): 893-900.

Smith T (2010) Technological change in capitalism: Some Marxian themes. Cambridge Journal of Economics 34: 203-212.

Stabrowski F (2017) 'People as businesses': Airbnb and urban micro-entrepreneurialism in New York City. Cambridge Journal of Regions, Economy and Society 10: 327-347.

Tieman R (2017) Barcelona: Smart city revolution in progress. Financial Times, 26 October. Available at: https://www.ft.com/content/6d2 fe2a8-722c-11e7-93ff-99f383b09ff9 (accessed 14 June 2018).

Vanolo A (2014) Smartmentality: The smart city as disciplinary strategy. Urban Studies 51(5): 883-898.

Vox (2019) Barcelona's radical plan to take back streets from cars. Available at: https:// www.vox.com/energy-and-environment/2019/ 4/9/18300797/barcelona-spain-superblocksurban-plan (accessed 24 April 2019).

Walt V (2015) Barcelona: The most wired city in the world. Fortune, 29 July. Available at: http://fortune.com/2015/07/29/barcelona-wire d-city/ (accessed 5 June 2018). 